
supercritical fluid chromatography-mass spectrometry

\author{
Daisy N. Grace et al.
}

Correspondence to: Melissa M. Galloway (gallowam@lafayette.edu)

The copyright of individual parts of the supplement might differ from the CC BY 4.0 License. 
Table S1. Information and properties from each of the columns tested in this analysis.

\begin{tabular}{|c|c|c|}
\hline Column & $\begin{array}{c}\text { Column manufacturer, part number, and } \\
\text { parameters }\end{array}$ & Stationary phase properties \\
\hline BEH C18 & $\begin{array}{l}\text { ACQUITY UPLC } ® \text { BEH C18, } 186002350, \\
130 \AA \text { A pore size, } 1.7 \mu \mathrm{m} \text { particles, } 2.1 \times 50 \mathrm{~mm}\end{array}$ & $\begin{array}{c}\text { Trifunctionally bonded BEH phase that is } \\
\text { stable from } \mathrm{pH} 1-12 \text {. Traditional nonpolar } \\
\text { interactions. }\end{array}$ \\
\hline HILIC & $\begin{array}{c}\text { CORTECSTM UPLC } ® \text { HILIC, } 186007104,90 \\
\AA \text { pore size, } 1.6 \mu \mathrm{m} \text { particles, } 2.1 \times 50 \mathrm{~mm}\end{array}$ & $\begin{array}{c}\text { Stable from } \mathrm{pH} \text { 1-5, intended for extremely } \\
\text { polar compounds. Unbonded stationary } \\
\text { phase. }\end{array}$ \\
\hline BEH Amide & $\begin{array}{l}\text { ACQUITY UPLC } \AA \text { BEH Amide, } 186004800 \text {, } \\
130 \AA \text { pore size, } 1.7 \mu \mathrm{m} \text { particles, } 2.1 \times 50 \mathrm{~mm}\end{array}$ & $\begin{array}{l}\text { Trifunctionally bonded amide phase, stable } \\
\text { from pH 2-12. Intended for compounds with } \\
\text { a wide range of polarities, including those } \\
\text { that are too polar for many RPLC columns. }\end{array}$ \\
\hline BEH 2-EP & $\begin{array}{c}\text { Viridis UPC }{ }^{2} \mathrm{TM} \text { BEH 2-Ethylpyridine, } \\
186006578,130 \AA \text { pore size, } 1.7 \mu \mathrm{m} \text { particles, } \\
2.1 \mathrm{~mm} \times 100 \mathrm{~mm}\end{array}$ & $\begin{array}{l}\text { Designed for good retention without the use } \\
\text { of additives, less polar than the similar BEH } \\
\text { column. }\end{array}$ \\
\hline BEH & 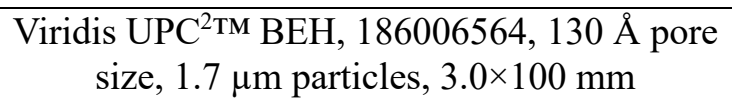 & $\begin{array}{l}\text { Ethylene bridged hybrid particles for } \\
\text { interaction with polar functional groups. }\end{array}$ \\
\hline
\end{tabular}


Table S2: Mobile phase conditions used in this study. Due to the similarity of separations, all methanol-based modifiers (methanol and methanol with $10 \mathrm{mM}$ formic acid additive or $10 \mathrm{mM}$ ammonium formate additive) used the same mobile phase gradient. All flow rates were $1.0 \mathrm{~mL} / \mathrm{min}$ total flow.

\begin{tabular}{|c|c|c|c|c|c|c|}
\hline & \multicolumn{3}{|c|}{ Acetonitrile } & \multicolumn{3}{|c|}{ Methanol-based modifiers } \\
\hline \multirow{7}{*}{ ВЕН C18 } & Time (min) & $\% \mathrm{CO}_{2}$ & $\% A C N$ & Time (min) & $\% \mathrm{CO}_{2}$ & \% Modifier \\
\hline & 0 & 99.5 & 0.5 & 0 & 100.0 & 0.0 \\
\hline & 2 & 99.0 & 1.0 & 5 & 100.0 & 0.0 \\
\hline & 20 & 55.0 & 45.0 & 15 & 55.0 & 45.0 \\
\hline & 26 & 55.0 & 45.0 & 26 & 55.0 & 45.0 \\
\hline & 27 & 99.5 & 0.5 & 27 & 100.0 & 0.0 \\
\hline & 30 & 99.5 & 0.5 & 30 & 100.0 & 0.0 \\
\hline \multirow{7}{*}{ HILIC } & Time (min) & $\% \mathrm{CO}_{2}$ & $\% \mathrm{ACN}$ & Time (min) & $\% \mathrm{CO}_{2}$ & \% Modifier \\
\hline & 0 & 100.0 & 0.0 & 0 & 100.0 & 0.0 \\
\hline & 2 & 100.0 & 0.0 & 5 & 100.0 & 0.0 \\
\hline & 20 & 55.0 & 45.0 & 15 & 55.0 & 45.0 \\
\hline & 27 & 55.0 & 45.0 & 26 & 55.0 & 45.0 \\
\hline & 28 & 100.0 & 0.0 & 27 & 100.0 & 0.0 \\
\hline & 30 & 100.0 & 0.0 & 30 & 100.0 & 0.0 \\
\hline \multirow{7}{*}{ BEH Amide } & Time (min) & $\% \mathrm{CO}_{2}$ & $\% \mathrm{ACN}$ & Time (min) & $\% \mathrm{CO}_{2}$ & \% Modifier \\
\hline & 0 & 100.0 & 0.0 & 0 & 99.0 & 1.0 \\
\hline & 2 & 100.0 & 0.0 & 2 & 99.0 & 1.0 \\
\hline & 20 & 55.0 & 45.0 & 20 & 55.0 & 45.0 \\
\hline & 27 & 55.0 & 45.0 & 27 & 55.0 & 45.0 \\
\hline & 28 & 100.0 & 0.0 & 28 & 99.0 & 1.0 \\
\hline & 30 & 100.0 & 0.0 & 30 & 99.0 & 1.0 \\
\hline \multirow{8}{*}{ ВEH 2-EP } & Time (min) & $\% \mathrm{CO}_{2}$ & $\% \mathrm{ACN}$ & Time (min) & $\% \mathrm{CO}_{2}$ & \% Modifier \\
\hline & 0 & 99.0 & 1.0 & 0 & 100.0 & 0.0 \\
\hline & 2 & 99.0 & 1.0 & 2 & 100.0 & 0.0 \\
\hline & 8 & 92.0 & 8.0 & 8 & 98.0 & 2.0 \\
\hline & 22 & 55.0 & 45.0 & 20 & 55.0 & 45.0 \\
\hline & 27 & 55.0 & 45.0 & 27 & 55.0 & 45.0 \\
\hline & 28 & 99.0 & 1.0 & 28 & 99.0 & 1.0 \\
\hline & 30 & 99.0 & 1.0 & 30 & 99.0 & 1.0 \\
\hline \multirow{8}{*}{ ВEH } & Time (min) & $\% \mathrm{CO}_{2}$ & $\% \mathrm{ACN}$ & Time (min) & $\% \mathrm{CO}_{2}$ & \% Modifier \\
\hline & 0 & 99.0 & 1.0 & 0 & 99.0 & 1.0 \\
\hline & 2 & 99.0 & 1.0 & 2 & 99.0 & 1.0 \\
\hline & 8 & 92.0 & 8.0 & 10 & 83.0 & 17.0 \\
\hline & 22 & 55.0 & 45.0 & 15 & 55.0 & 45.0 \\
\hline & 27 & 55.0 & 45.0 & 26 & 55.0 & 45.0 \\
\hline & 28 & 99.0 & 1.0 & 27 & 99.0 & 1.0 \\
\hline & 30 & 99.0 & 1.0 & 30 & 99.0 & 1.0 \\
\hline
\end{tabular}


Table S3. Masses observed in this study, along with previously reported proposed chemical structures. Retention times given are for peaks observed using the BEH column with pure methanol as the mobile phase modifier. Retention times shown in bold indicate most intense signals. Fragments are given for those peaks that show significant fragmentation.

\begin{tabular}{|c|c|c|c|c|c|}
\hline $\mathrm{m} / \mathrm{z}$ & $\begin{array}{l}\text { Neutral chemical } \\
\text { formula }\end{array}$ & Proposed neutral structure & $\begin{array}{l}\text { Retention time } \\
\quad(\min )\end{array}$ & Fragment $m / z$ & Reference \\
\hline 59 & & & $4.5,6.9,15$ & 42 & This study \\
\hline 81 & & & 6.9 & $\begin{array}{l}\text { No significant } \\
\text { fragments }\end{array}$ & This study \\
\hline 83 & $\mathrm{C}_{4} \mathrm{H}_{7} \mathrm{~N}_{2}$ & & $5.5, \mathbf{1 2 . 8}, 14.8$ & $\begin{array}{c}5.5 \text { and } 12.8: 41 \\
56\end{array}$ & $\begin{array}{c}\text { (Kampf et al., } \\
\text { 2016) }\end{array}$ \\
\hline 87 & & & $\begin{array}{c}1.2, \mathbf{2 . 8}, \mathbf{4 . 5} \\
15.6\end{array}$ & $\begin{array}{c}2.8 \text { and } 4.5: 43 \\
45,59\end{array}$ & This study \\
\hline 97 & $\mathrm{C}_{5} \mathrm{H}_{8} \mathrm{~N}_{2}$ & & $5.2,8.3, \mathbf{1 4 . 3}$ & $\begin{array}{r}8.3: 42,69 \\
14.3: 42,56\end{array}$ & $\begin{array}{l}\text { (De Haan et al., } \\
\text { 2011; Hawkins et } \\
\text { al., 2018) }\end{array}$ \\
\hline 98 & & & $\mathbf{2 . 0}, 3.9,5.0$ & $2.0: 43,56,70$ & This study \\
\hline 109 & $\mathrm{C}_{6} \mathrm{H}_{8} \mathrm{~N}_{2}$ & & 3.7 & $\begin{array}{c}41,55,68,82 \\
93\end{array}$ & $\begin{array}{c}\text { (Lin et al., 2015; } \\
\text { Hawkins et al., } \\
\text { 2018) }\end{array}$ \\
\hline 113 & & & 3.9 & $\begin{array}{c}95,85,67,45 \\
43\end{array}$ & This study \\
\hline 117 & & & $\mathbf{2 . 7}, 4.3,4.9,5.8$ & $\begin{array}{l}\text { 2.7: } 45,59,87 \\
4.3: 43,57,85 \\
4.9: 43,71,99 \\
5.8: 41,59\end{array}$ & This study \\
\hline 122 & & & 3.9, 14.7 & 56,104 & This study \\
\hline 125 & $\mathrm{C}_{6} \mathrm{H}_{8} \mathrm{ON}_{2}$ & $\mathrm{O}$ & 5.5 & $43,56,83,107$ & $\begin{array}{l}\text { (De Haan et al., } \\
\text { 2011; Kampf et } \\
\text { al., 2012; Lin et } \\
\text { al., 2015; Hawkins } \\
\quad \text { et al., 2018) }\end{array}$ \\
\hline 126 & $\mathrm{C}_{6} \mathrm{H}_{7} \mathrm{O}_{2} \mathrm{~N}$ & & $\begin{array}{c}2.2,3.6,4.1 \\
5.0, \mathbf{1 3 . 4}, \mathbf{1 4 . 9}\end{array}$ & $\begin{array}{l}2.2: 43,84,111 \\
13.4 \text { and } 14.9: \\
42,55,70,80 \\
98,108\end{array}$ & $\begin{array}{l}\text { (Sareen et al., } \\
\text { 2010; Lin et al., } \\
\text { 2015) }\end{array}$ \\
\hline 127 & & & $2.2, \mathbf{5 . 8}, 8.2$ & $\begin{array}{r}5.8: 83 \\
8.2: 89,56\end{array}$ & This study \\
\hline 131 & & & $\mathbf{1 . 7}, \mathbf{3 . 8}, 4.6$ & $\begin{array}{c}1.7: 45,59,73 \\
3.8: 43,45,67 \\
85,113 \\
4.6: 45,59,87\end{array}$ & This study \\
\hline
\end{tabular}




\begin{tabular}{|c|c|c|c|c|c|}
\hline $\mathrm{m} / \mathrm{z}$ & $\begin{array}{l}\text { Neutral chemical } \\
\text { formula }\end{array}$ & Proposed neutral structure & $\begin{array}{l}\text { Retention time } \\
\quad(\min )\end{array}$ & Fragment $m / z$ & Reference \\
\hline 139 & & & $\begin{array}{c}5.2,5.3,5.8 \\
5.9,6.7, \mathbf{1 1 . 4} \\
\mathbf{1 2 . 3}\end{array}$ & \begin{tabular}{l}
\multicolumn{1}{c}{$5.2: 97$} \\
$5.3: 57,83$ \\
$12.3: 57,83,96$ \\
139
\end{tabular} & This study \\
\hline 144 & $\mathrm{C}_{6} \mathrm{H}_{9} \mathrm{O}_{3} \mathrm{~N}$ & & $\begin{array}{l}\text { 2.3, 3.9, 4.2, } \\
\quad 8.3,8.6\end{array}$ & \begin{tabular}{l}
\multicolumn{1}{c}{$3.9: 56,74$} \\
$4.2: 102,126$ \\
$8.3: 60,74,102$ \\
$8.6: 74$
\end{tabular} & $\begin{array}{l}\text { (Sareen et al., } \\
\text { 2010; Lin et al., } \\
\text { 2015) }\end{array}$ \\
\hline 162 & $\begin{array}{c}\mathrm{C}_{9} \mathrm{H}_{11} \mathrm{~N}_{3} \\
\mathrm{C}_{6} \mathrm{H}_{11} \mathrm{O}_{4} \mathrm{~N}\end{array}$ & & 7.7, 7.9, 15.6 & $\begin{array}{c}\text { 7.7: } 42,66,80 \\
94,107,121 \\
135,147 \\
15.6: 42,88\end{array}$ & $\begin{array}{c}\text { (Lin et al., 2015; } \\
\text { Hawkins et al., } \\
\text { 2018) } \\
\text { (Sareen et al., } \\
\text { 2010; Lin et al., } \\
\text { 2015) }\end{array}$ \\
\hline 165 & $\mathrm{C}_{9} \mathrm{H}_{12} \mathrm{ON}_{2}$ & & $4.8,6.1,6.7$ & $\begin{array}{c}6.1 \text { and } 6.7: 43 \\
123,147\end{array}$ & (Lin et al., 2015) \\
\hline 166 & $\mathrm{C}_{9} \mathrm{H}_{11} \mathrm{O}_{2} \mathrm{~N}$ & & $\begin{array}{c}\text { 4.0, 4.5, 7.4, } \\
\quad 9.3,10.0\end{array}$ & $\begin{array}{c}4.0: 42,79,124, \\
148 \\
9.3: 96,110,138\end{array}$ & (Lin et al., 2015) \\
\hline 167 & $\mathrm{C}_{9} \mathrm{H}_{10} \mathrm{O}_{3}$ & & $\begin{array}{l}\mathbf{1 . 8}, 2.1,2.5, \\
4.3,5.9,6.1, \\
7.3,10.3,11\end{array}$ & $\begin{array}{l}\text { 1.8: } 43,79,93 \\
107,125,149 \\
7.3: 43,97\end{array}$ & (Lin et al., 2015) \\
\hline 169 & & & $\begin{array}{l}\text { 1.3, 4.3, 4.6, } \\
\mathbf{4 . 8}, 4.7,6.1, \\
\mathbf{7 . 6}, 8.3,14.7\end{array}$ & $\begin{array}{c}4.3: 43,53,109, \\
151 \\
4.4: 59,71,83 \\
111,127\end{array}$ & This study \\
\hline 178 & $\mathrm{C}_{9} \mathrm{H}_{11} \mathrm{~N}_{3} \mathrm{O}$ & & $\begin{array}{c}1.9,6.9,7.2 \\
\mathbf{8 . 3}, 9.3,9.8,9.9\end{array}$ & $\begin{array}{l}\text { 6.9: } 82,114 \\
\text { 9.8: } 148\end{array}$ & $\begin{array}{l}\text { (Aiona et al., } \\
\text { 2017) }\end{array}$ \\
\hline 180 & $\mathrm{C}_{9} \mathrm{H}_{9} \mathrm{NO}_{3}$ & & $3.2,3.8,4.0,8.3$ & $\begin{array}{c}3.8: 45,57,89 \\
101,107 \\
8.3: 84,98,110\end{array}$ & $\begin{array}{c}\text { (Lin et al., 2015; } \\
\text { Hawkins et al., } \\
\text { 2018) }\end{array}$ \\
\hline 181 & $\mathrm{C}_{9} \mathrm{H}_{12} \mathrm{~N}_{2} \mathrm{O}_{2}$ & & $\begin{array}{c}4.5,5.5, \mathbf{5 . 8} \\
7.3,9.3,9.5\end{array}$ & $\begin{array}{c}5.8: 139 \\
7.3: 83,99,121\end{array}$ & $\begin{array}{c}\text { (Hawkins et al., } \\
\text { 2018) }\end{array}$ \\
\hline 183 & $\mathrm{C}_{9} \mathrm{H}_{14} \mathrm{O}_{2} \mathrm{~N}_{2}$ & & $\begin{array}{l}\text { 4.2, 6.8, } 9.2 \\
\quad 9.5,13.4\end{array}$ & $\begin{array}{l}\text { 4.2: } 109,151 \\
\text { 9.2: } 141 \\
\text { 9.5: } 112 \\
\text { 13.4: } 110,123\end{array}$ & (Lin et al., 2015) \\
\hline
\end{tabular}




\begin{tabular}{|c|c|c|c|c|c|}
\hline $\mathrm{m} / \mathrm{z}$ & $\begin{array}{l}\text { Neutral chemical } \\
\text { formula }\end{array}$ & Proposed neutral structure & $\begin{array}{l}\text { Retention time } \\
\quad(\min )\end{array}$ & Fragment $m / z$ & Reference \\
\hline 190 & & & $\begin{array}{l}1.8, \mathbf{4 . 8}, 5.0, \\
\mathbf{5 . 3}, \mathbf{5 . 4}, 5.6\end{array}$ & $\begin{array}{c}4.8: 106,150, \\
162 \\
5.0: 69,148 \\
5.3: 94,106, \\
150,162 \\
5.4: 83,109,148, \\
163,172\end{array}$ & This study \\
\hline 195 & $\mathrm{C}_{9} \mathrm{H}_{10} \mathrm{~N}_{2} \mathrm{O}_{3}$ & O & $5.0, \mathbf{5 . 3}, 5.6$ & 5.3: 98,139 & $\begin{array}{l}\text { (Aiona et al., } \\
\text { 2017) }\{\text { Aiona, } \\
2017 \# 291\}\end{array}$ \\
\hline 196 & $\mathrm{C}_{9} \mathrm{H}_{13} \mathrm{O}_{2} \mathrm{~N}_{3}$ & $\mathrm{NH}_{2}$ & $\begin{array}{c}\text { 7.6, 7.8, } 9.8, \\
10.8,14.7\end{array}$ & $\begin{array}{l}\text { 7.6: } 43,126,178 \\
7.8: 67,79,84, \\
95,122,136, \\
164 \\
9.8: 95,138,168 \\
10.8: 83,137, \\
154 \\
14.7: 150,178\end{array}$ & $\begin{array}{l}\text { (Sareen et al., } \\
\text { 2010; Lin et al., } \\
\text { 2015) }\end{array}$ \\
\hline 197 & $\mathrm{C}_{9} \mathrm{H}_{12} \mathrm{O}_{3} \mathrm{~N}_{2}$ & & $1.2,7.7,7.8, \mathbf{8 . 7}$ & $\begin{array}{l}1.2: 95 \\
7.8: 123,137, \\
151,179 \\
8.7: 83,97,109, \\
125,151,161, \\
179\end{array}$ & $\begin{array}{l}\text { (Sareen et al., } \\
\text { 2010; Lin et al., } \\
\text { 2015) }\end{array}$ \\
\hline 216 & $\mathrm{C}_{9} \mathrm{H}_{13} \mathrm{NO}_{5}$ & $\mathrm{OH}$ & $4.6,7.9,8.0,9.5$ & $\begin{array}{c}7.9 \text { and } 9.5: 174 \\
188\end{array}$ & $\begin{array}{c}\text { (Hawkins et al., } \\
\text { 2018) }\end{array}$ \\
\hline 224 & & & $\begin{array}{l}\mathbf{2 . 8}, 6.3,6.7 \\
7.2,8.3,8.4 \\
10.6\end{array}$ & $\begin{array}{l}2.8: 59,73,87, \\
\text { 103, } 117,189 \\
6.7: 43,122,140, \\
154,164,182, \\
206 \\
7.2: 182,194\end{array}$ & This study \\
\hline 232 & $\mathrm{C}_{12} \mathrm{H}_{13} \mathrm{O}_{2} \mathrm{~N}_{3}$ & & $\begin{array}{c}7.8,8.6,9.3 \\
10.1,10.4,10.8\end{array}$ & $\begin{array}{l}\text { 7.8: } 162 \\
9.3: 43,83,192, \\
204\end{array}$ & $\begin{array}{l}\text { (Lin et al., 2015; } \\
\text { Aiona et al., 2017) }\end{array}$ \\
\hline 234 & $\mathrm{C}_{12} \mathrm{H}_{11} \mathrm{NO}_{4}$ & 0 & $\begin{array}{c}3.6,7.9,8.6 \\
\mathbf{8 . 9}, 10.2,10.4 \\
10.8,10.9,11.1 \\
16.5\end{array}$ & $\begin{array}{l}\text { 7.9: } 109,110, \\
151,192 \\
8.9: 162,188, \\
216 \\
10.8: 216 \\
16.5: 188\end{array}$ & $\begin{array}{c}\text { (Hawkins et al., } \\
\text { 2018) }\end{array}$ \\
\hline
\end{tabular}




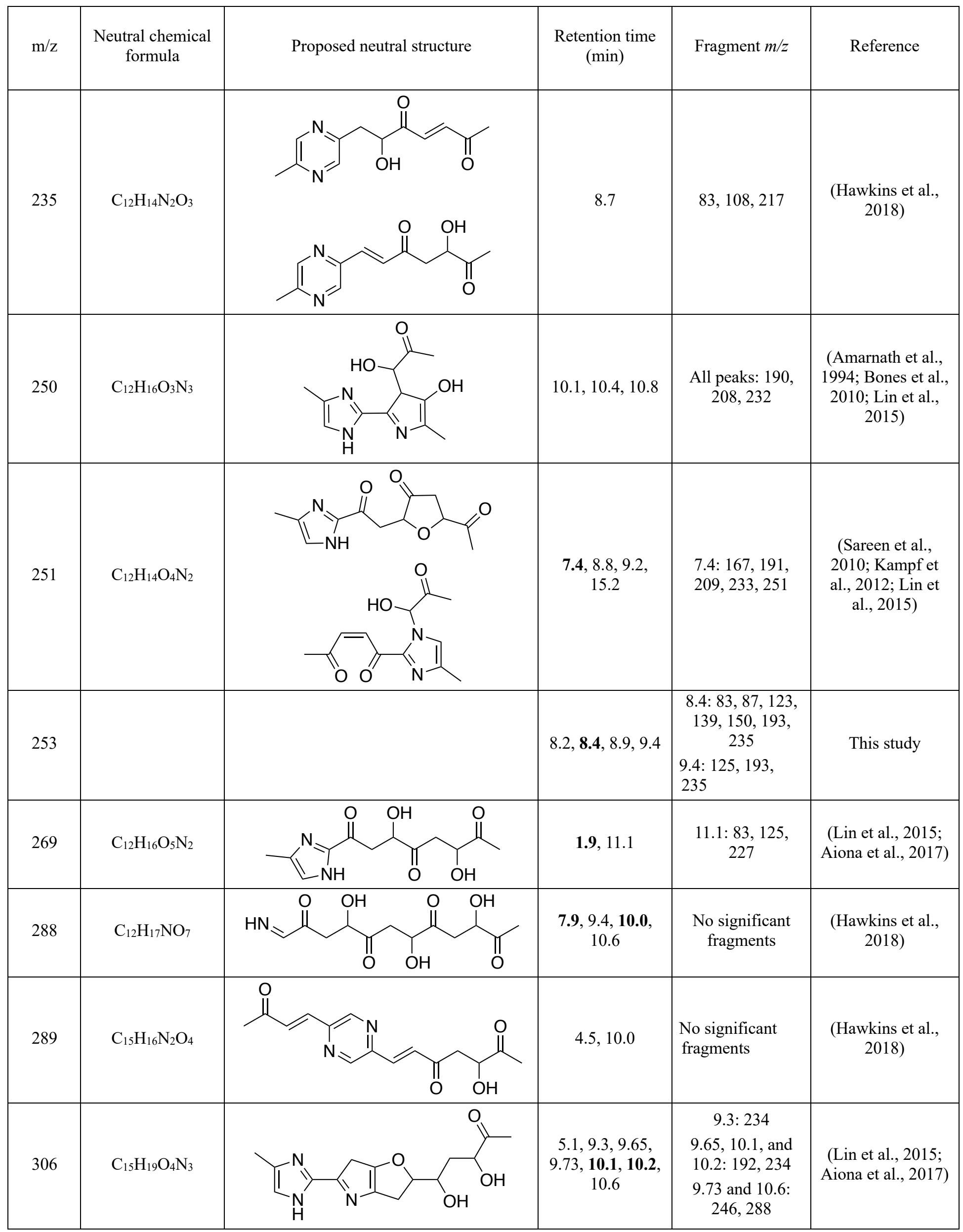




\begin{tabular}{|c|c|c|c|c|c|}
\hline $\mathrm{m} / \mathrm{z}$ & $\begin{array}{c}\text { Neutral chemical } \\
\text { formula }\end{array}$ & Proposed neutral structure & $\begin{array}{c}\text { Retention time } \\
\text { (min) }\end{array}$ & Fragment $m / z$ & Reference \\
\hline 323 & $\mathrm{C}_{15} \mathrm{H}_{18} \mathrm{~N}_{2} \mathrm{O}_{6}$ & & No significant & $\begin{array}{c}\text { (Lin et al., 2015; } \\
\text { Aiona et al., 2017) }\end{array}$ \\
\hline
\end{tabular}




\section{Mass Spectrometry}

\section{Column comparisons}

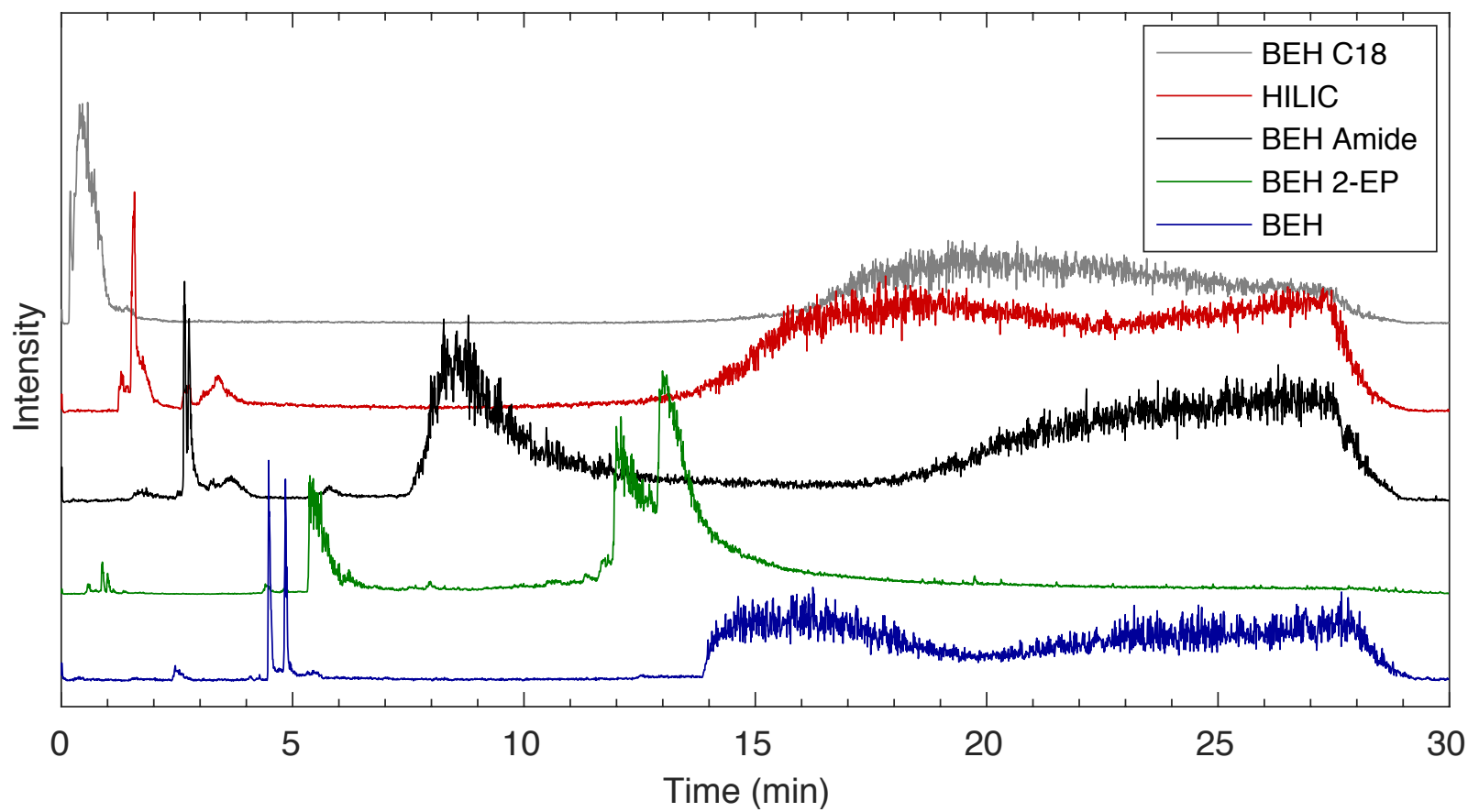

Figure S1: Comparison of EICs from five columns using acetonitrile modifier. The masses monitored are shown in Table S3. Note the drop in signal at 27 minutes (when the system switched back to initial conditions) indicating that compounds were still eluting from the column under the highest polarity solvent conditions.

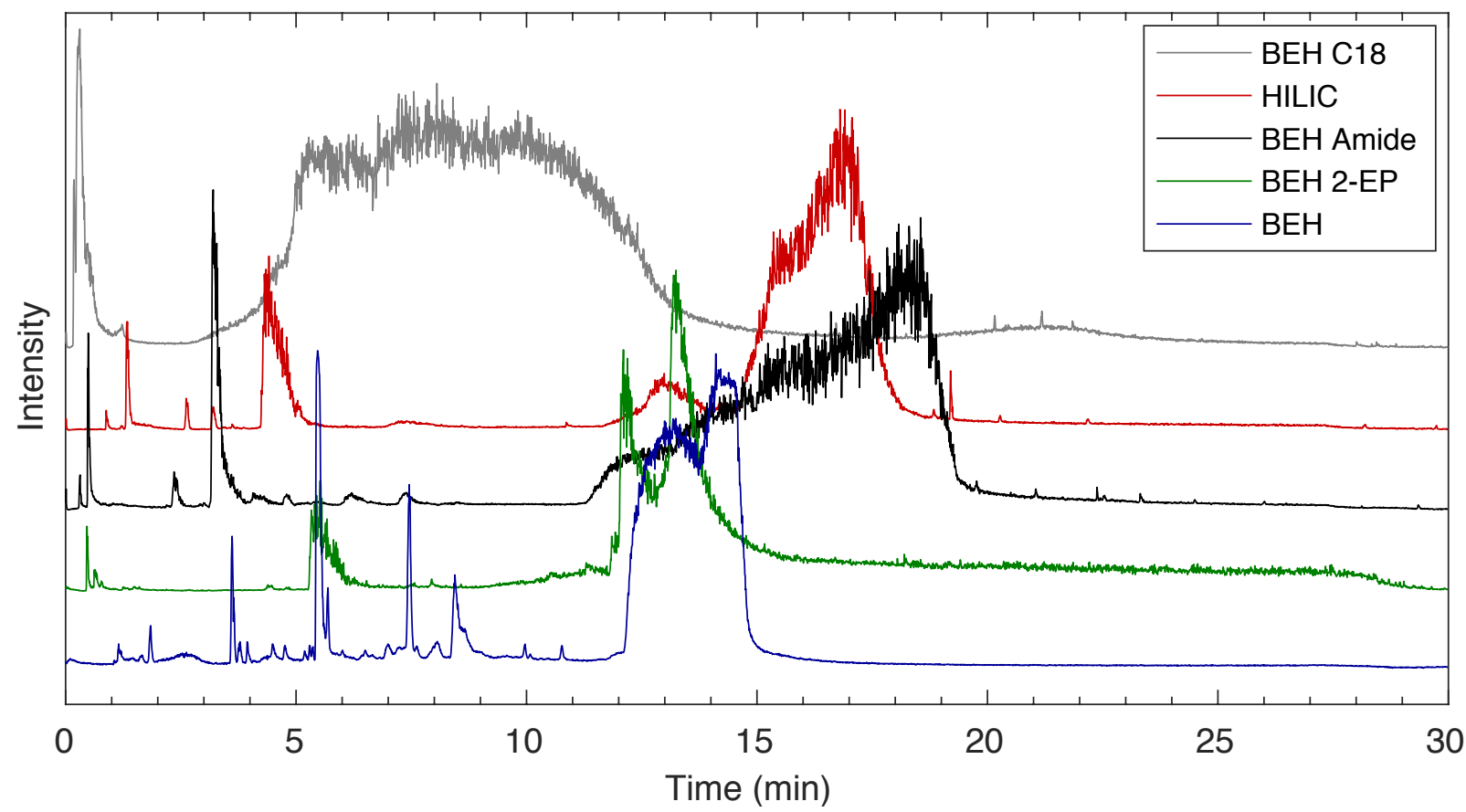

Figure S2: Comparison of EICs from five columns using methanol modifier with $10 \mathrm{mM}$ formic acid additive. The masses monitored are shown in Table S3. 


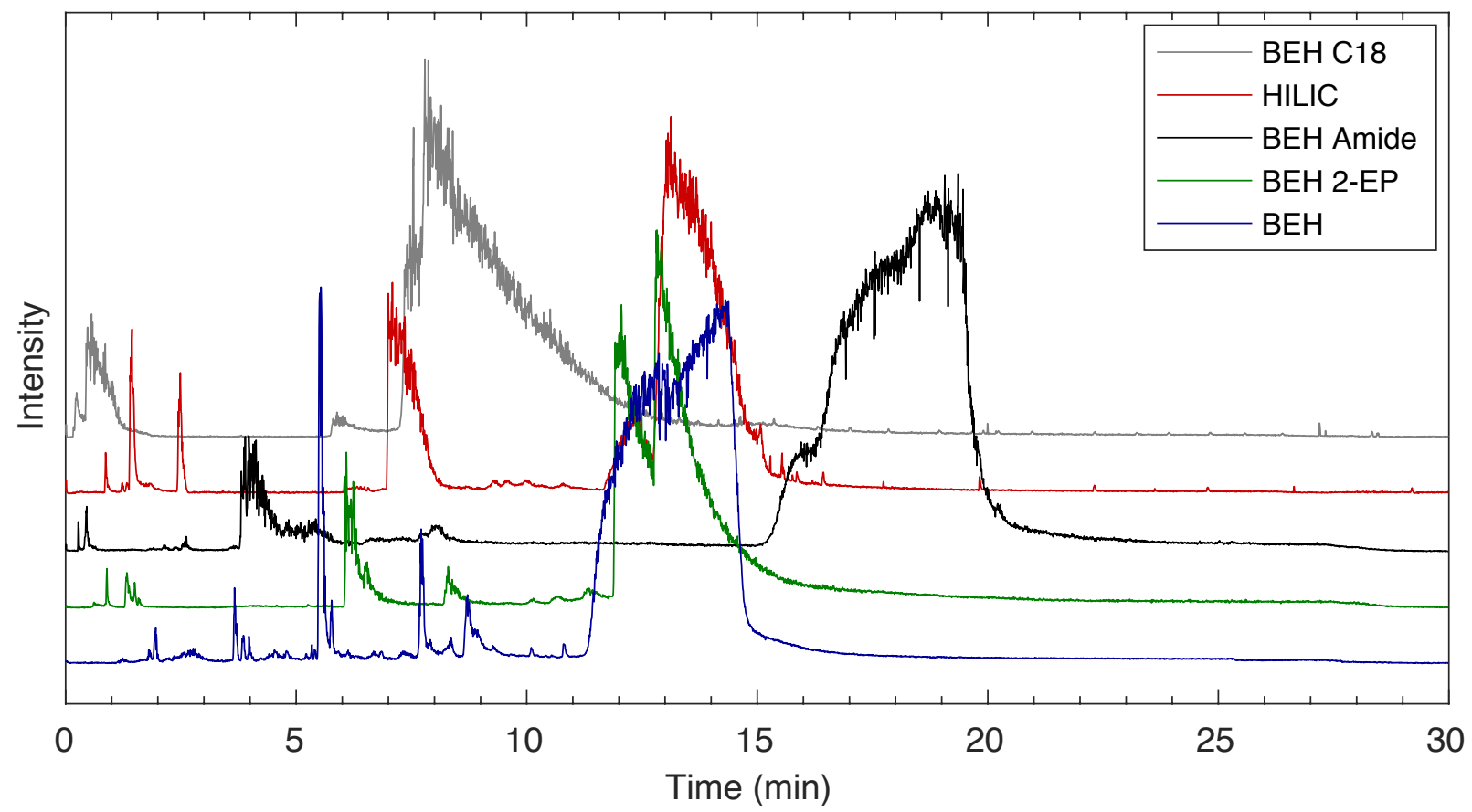

Figure S3: Comparison of EICs from five columns using methanol modifier. The masses monitored are shown in Table S3. 


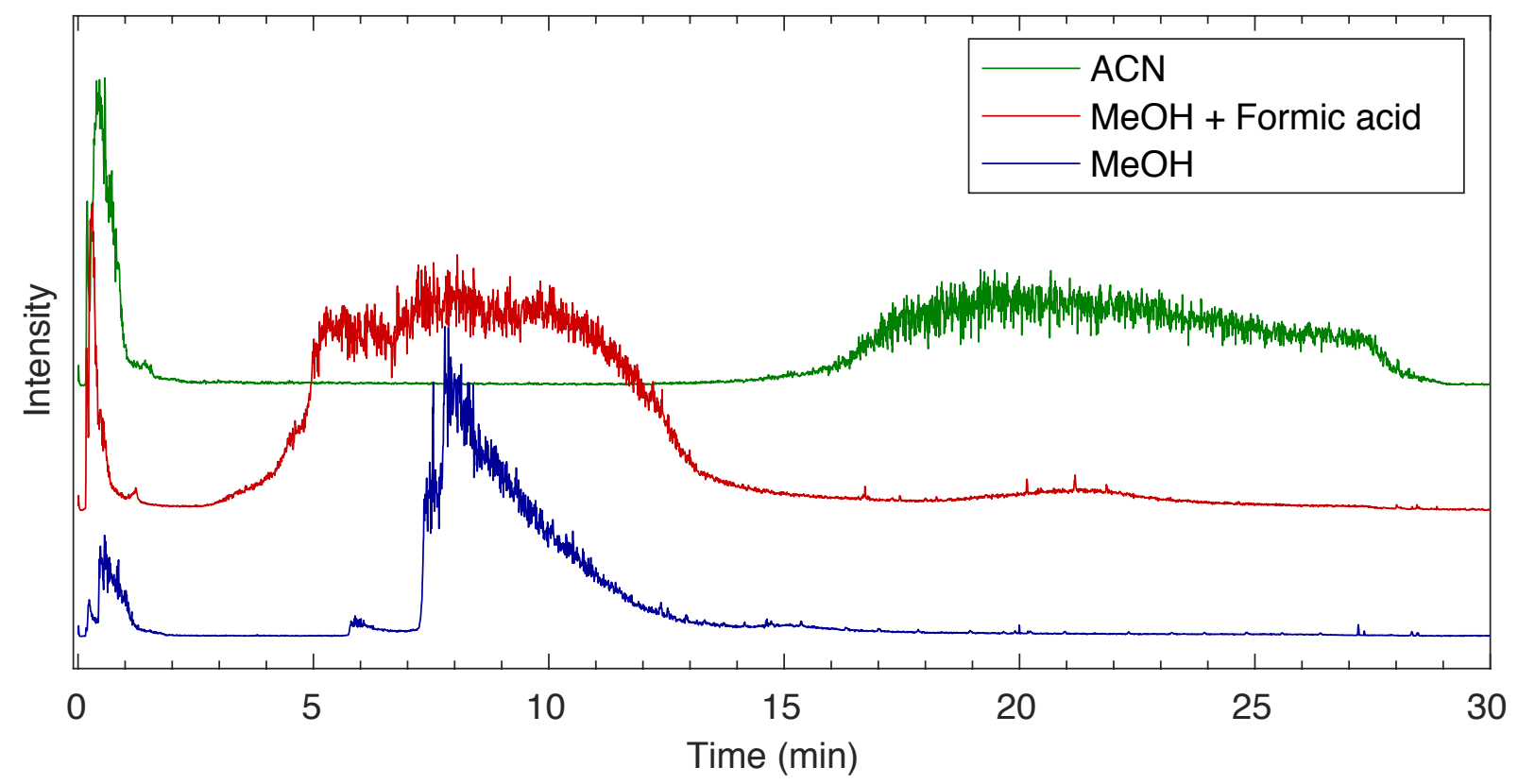

Figure S4: Comparison of EICs on the BEH C18 column using three different modifiers. The masses monitored are shown in Table S3.

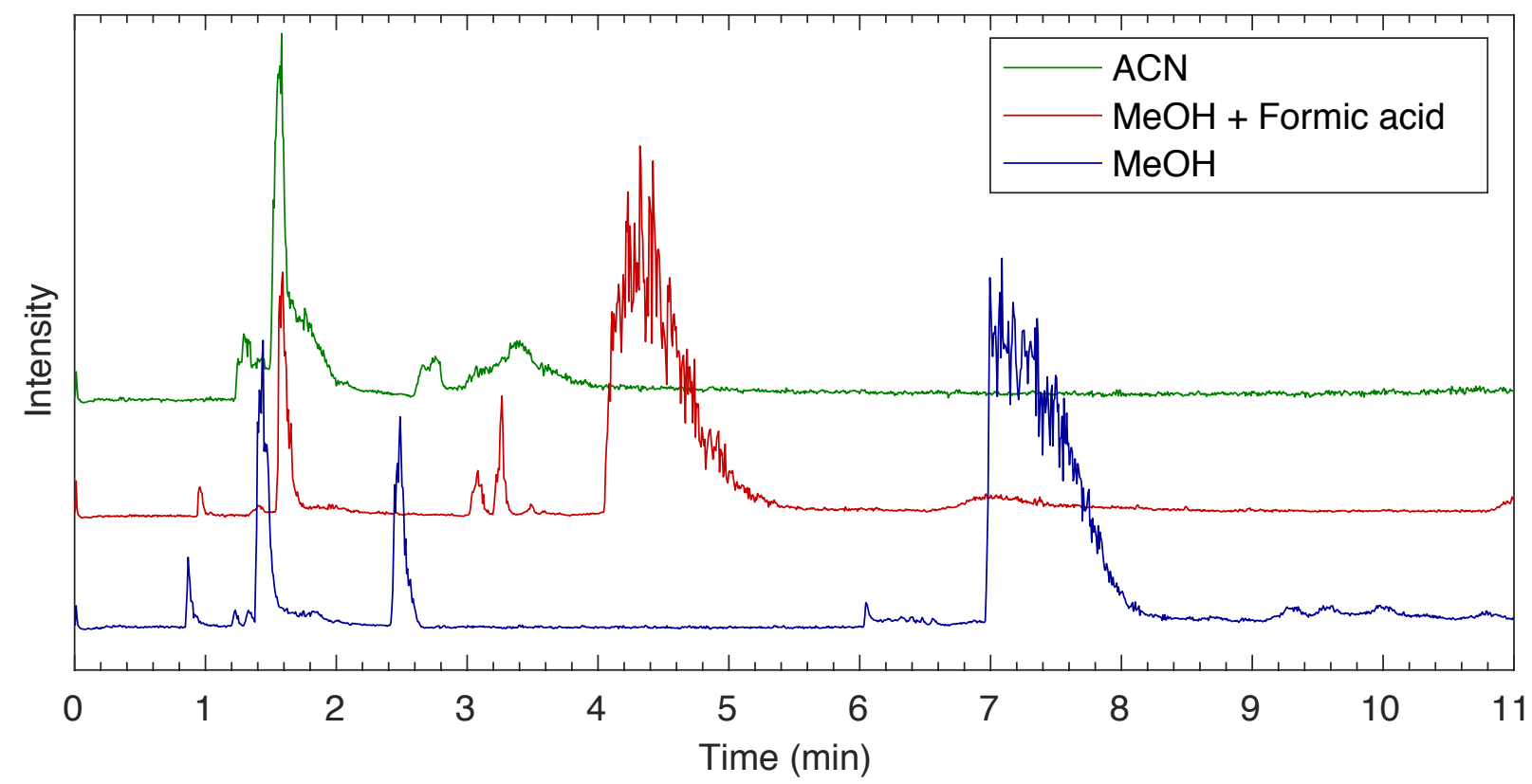

Figure S5: Comparison of EICs on the HILIC column using three different modifiers. The masses monitored are shown in Table S3. 


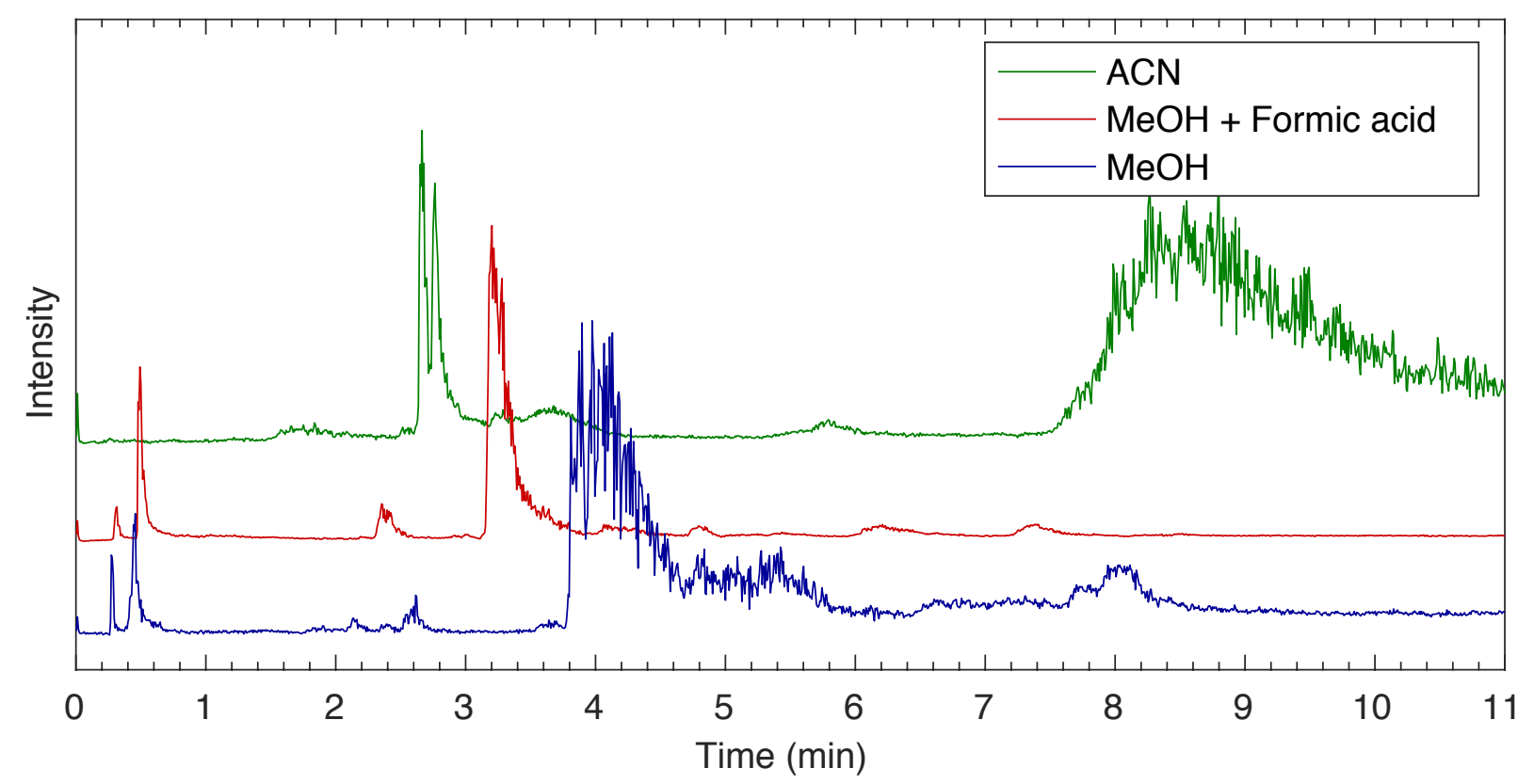

Figure S6: Comparison of EICs on the BEH Amide column using three different modifiers. The masses monitored are shown in Table S3.

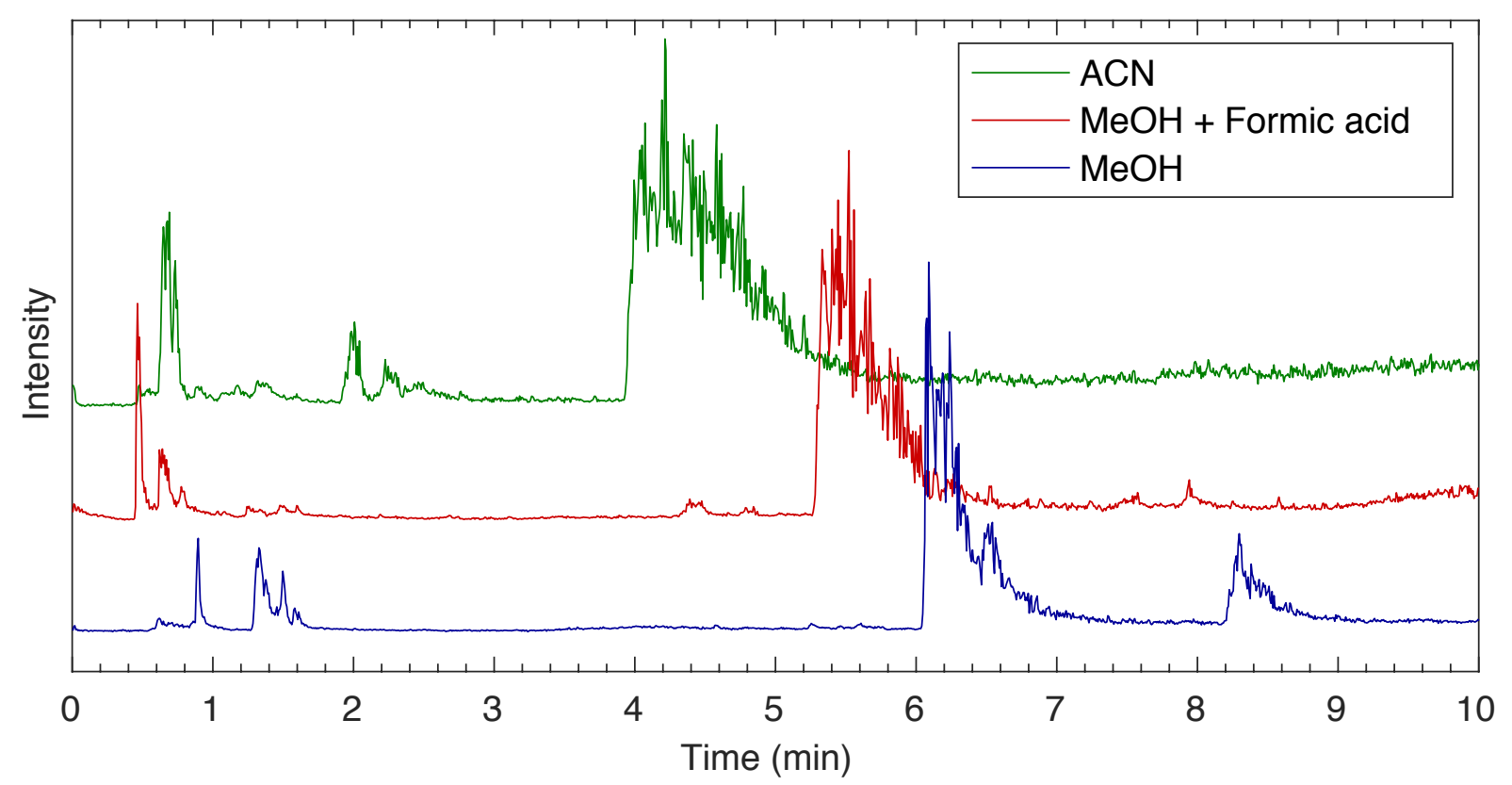

Figure S7: Comparison of EICs on the BEH 2-ethylpyridine (BEH 2-EP) column using three different modifiers. The masses monitored are shown in Table S3. 


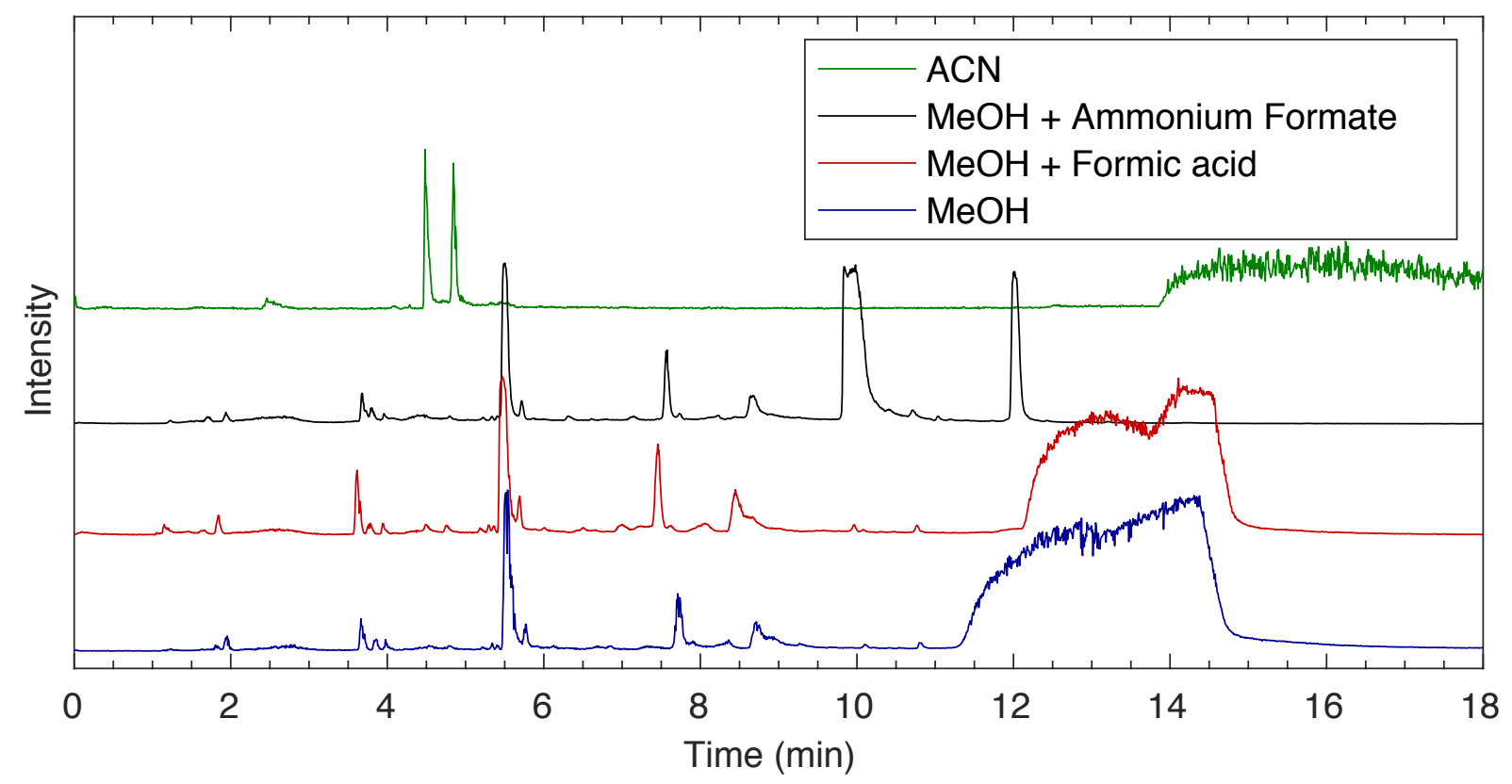

Figure S8: Comparison of EICs on the BEH (BEH) column using four different modifiers. The masses monitored are shown in Table S3. 

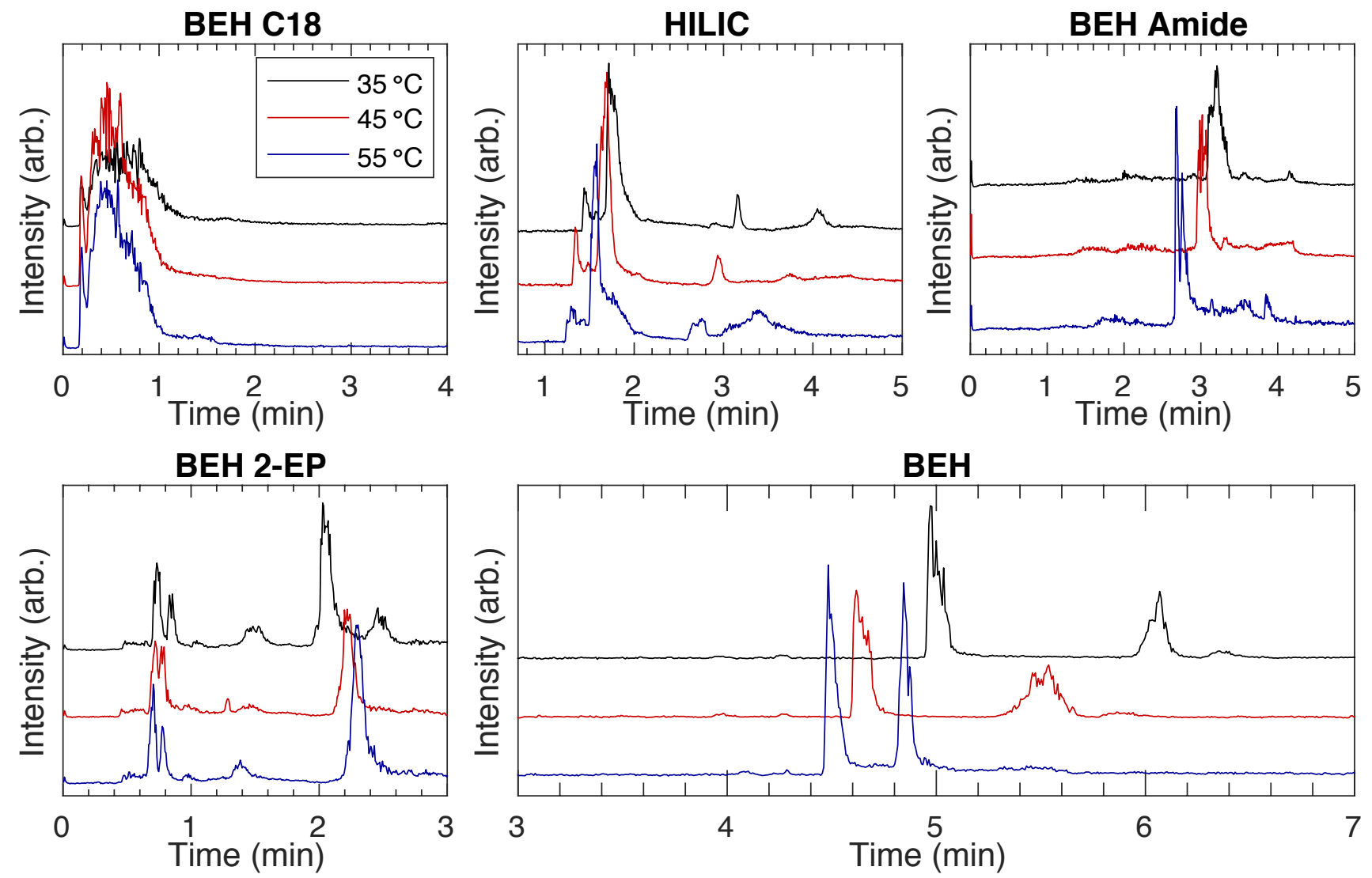

Figure S9: EICs showing effect of temperature changes on all columns using acetonitrile modifier. The masses monitored are shown in Table S3. 

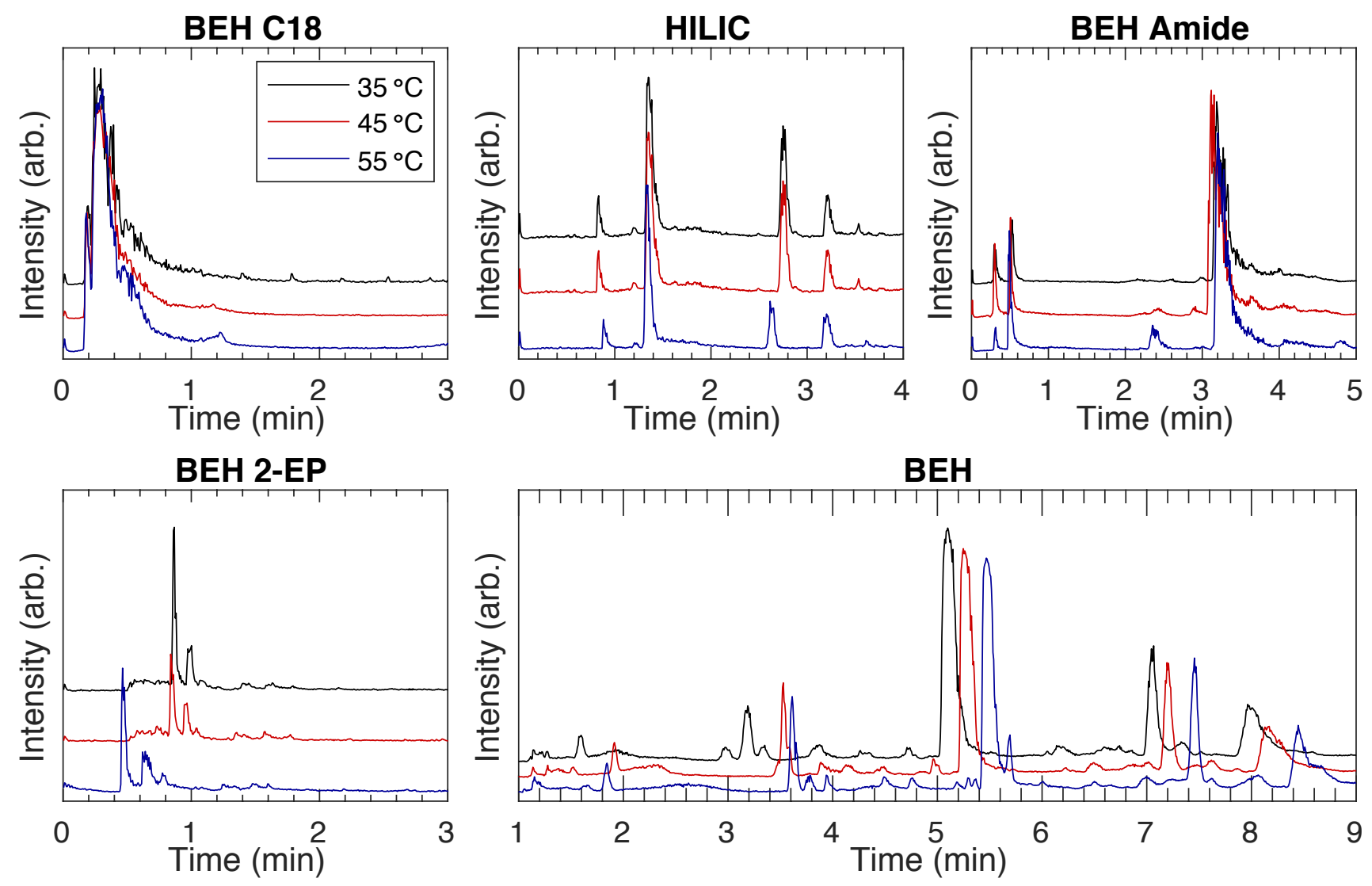

Figure S10: EICs showing effect of temperature changes on all columns using methanol modifier with $10 \mathrm{mM}$ formic acid as an additive. The masses monitored are shown in Table S3. 
BEH C18

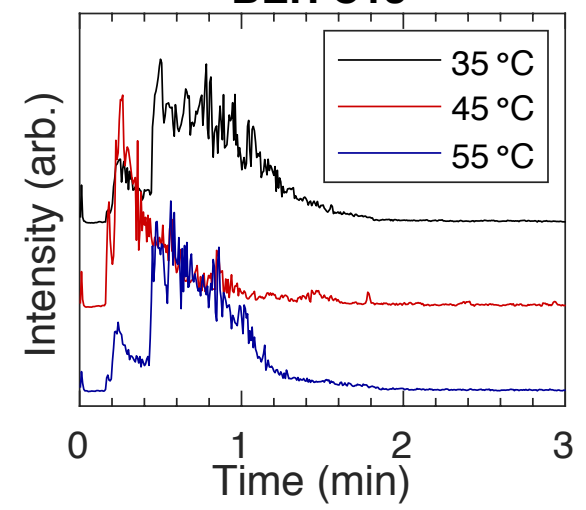

BEH 2-EP

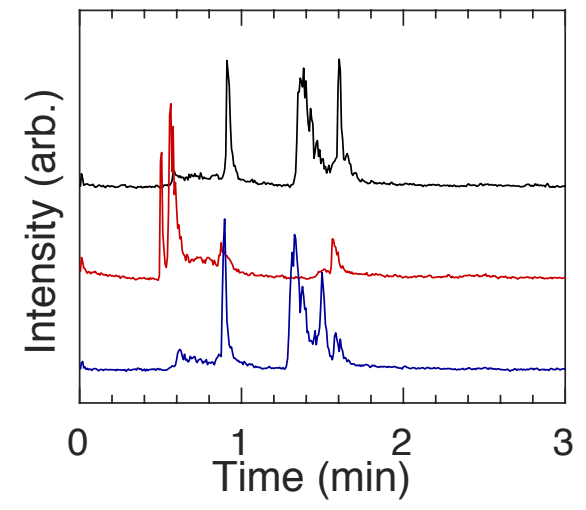

HILIC
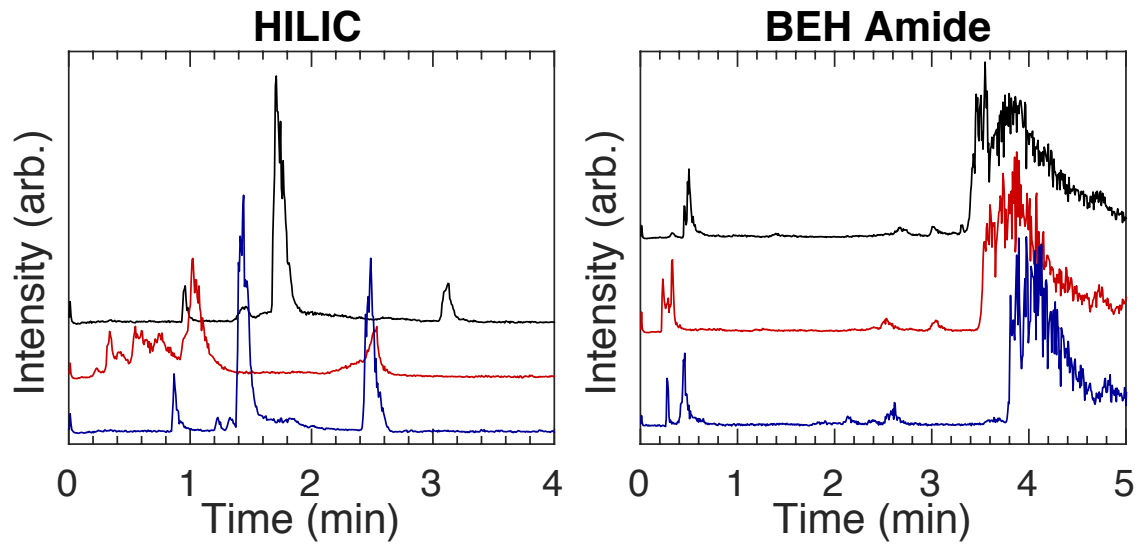

BEH

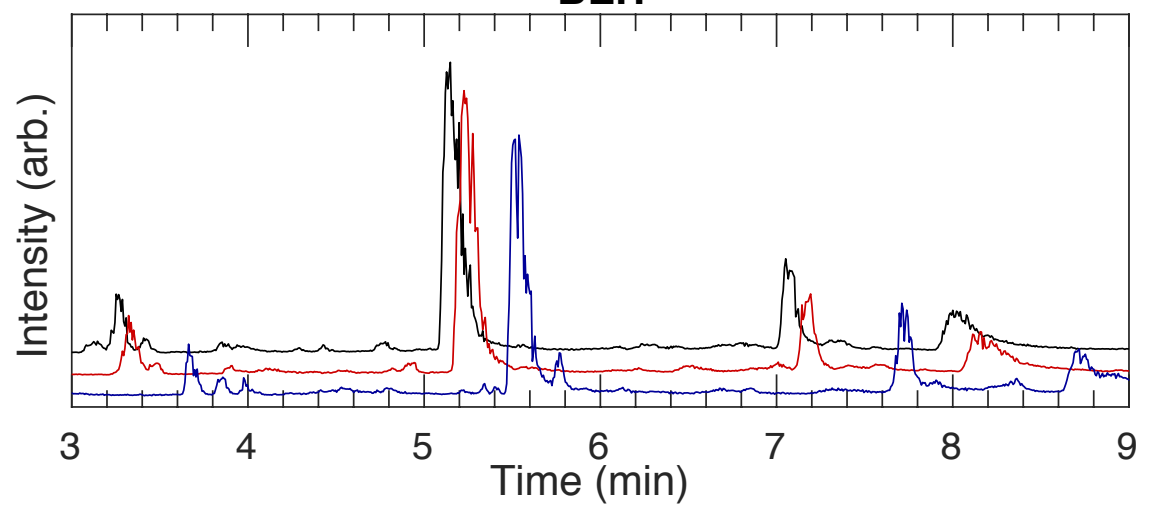

Figure S11: EICs showing effect of temperature changes on all columns using methanol modifier. The masses monitored are shown in Table S3.

\section{Mass spectrometry parameters}

Performing a scan over the entire mass region of interest supplies necessary information about the analytes present, but for improved sensitivity and signal to noise ratios, extracted ion chromatograms (EICs) were utilized extensively. Full spectral scans from $\mathrm{m} / \mathrm{z}$ 50-350 were used to identify possible products of interest, then subsequent samples monitored each of the identified masses. This process was repeated until as many features as possible were maintained to ensure that all compounds were accounted for. A comparison between a scan and the combined EIC data are shown in Figure S12. All masses observed in this study are given in Table S3, and all EICs are shown in Figure S14. Full spectral scans were also taken for each separation to ensure no new compounds were missed during analysis. All other chromatograms presented in this study are a combination of all the EIC signals in Table S3 and Figure S14.

For EIC collection, a mass window of $\pm 0.5 \mathrm{Da}$ from the desired mass is monitored. Therefore, it is possible to falsely identify masses within the system that are not real if an adjacent mass has a very high intensity. One example of this can be seen with the peak from $\mathrm{m} / z 97$ and 98 that elutes at $14.3 \mathrm{~min}$ in Figure S14. This peak is very intense at $m / z 97$ and shows up in $m / z 98$ at $\sim 10 \times$ lower intensity. This peak can also be seen at this lower intensity at $\mathrm{m} / \mathrm{z} 96$ (not shown), indicating that this is likely a result of the fact that a quadrupole mass spectrometer only has unit resolution and cannot easily distinguish between adjacent masses. It is possible to determine if a mass is found in a reaction mixture by analyzing masses within $1 \mathrm{Da}$ of the mass of interest. This was done here in order to ensure that all masses reported in Table $\mathbf{S 3}$ are not artifacts of the mass selector used. 


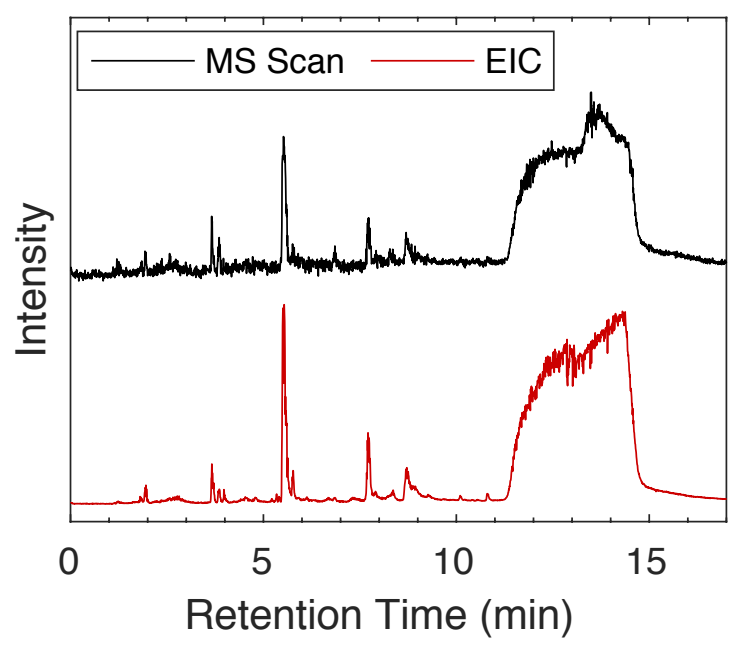

Figure S12. Comparison of the total MS scan (black) with the combined extracted ion chromatograms (EIC, red) of all masses monitored. The noise is significantly decreased in the EIC scan, but most spectral features are maintained.

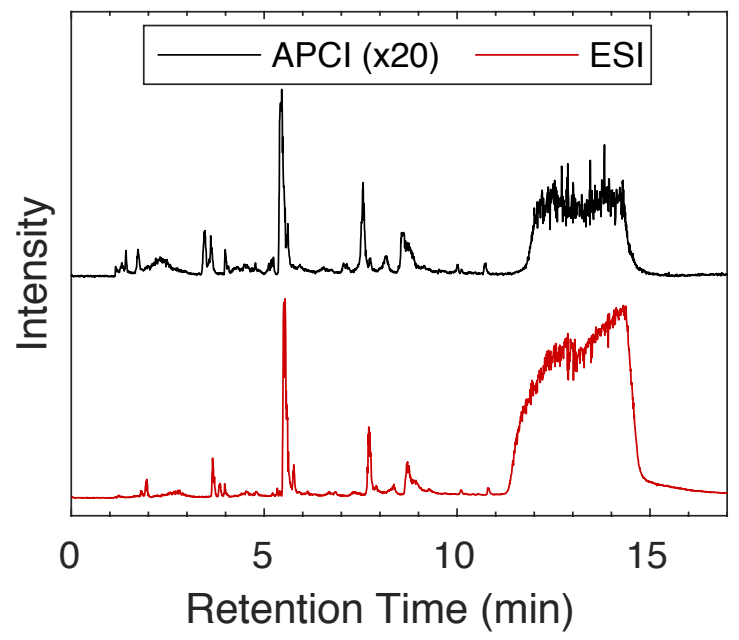

Figure S13. Electrospray ionization (ESI, red) and atmospheric pressure chemical ionization (APCI, black) combined extracted ion chromatograms. The APCI signal is multiplied by 20 for comparison with the ESI signal. Both ionization methods detected most peaks, but all peaks were detected by ESI and with significantly higher signal. 


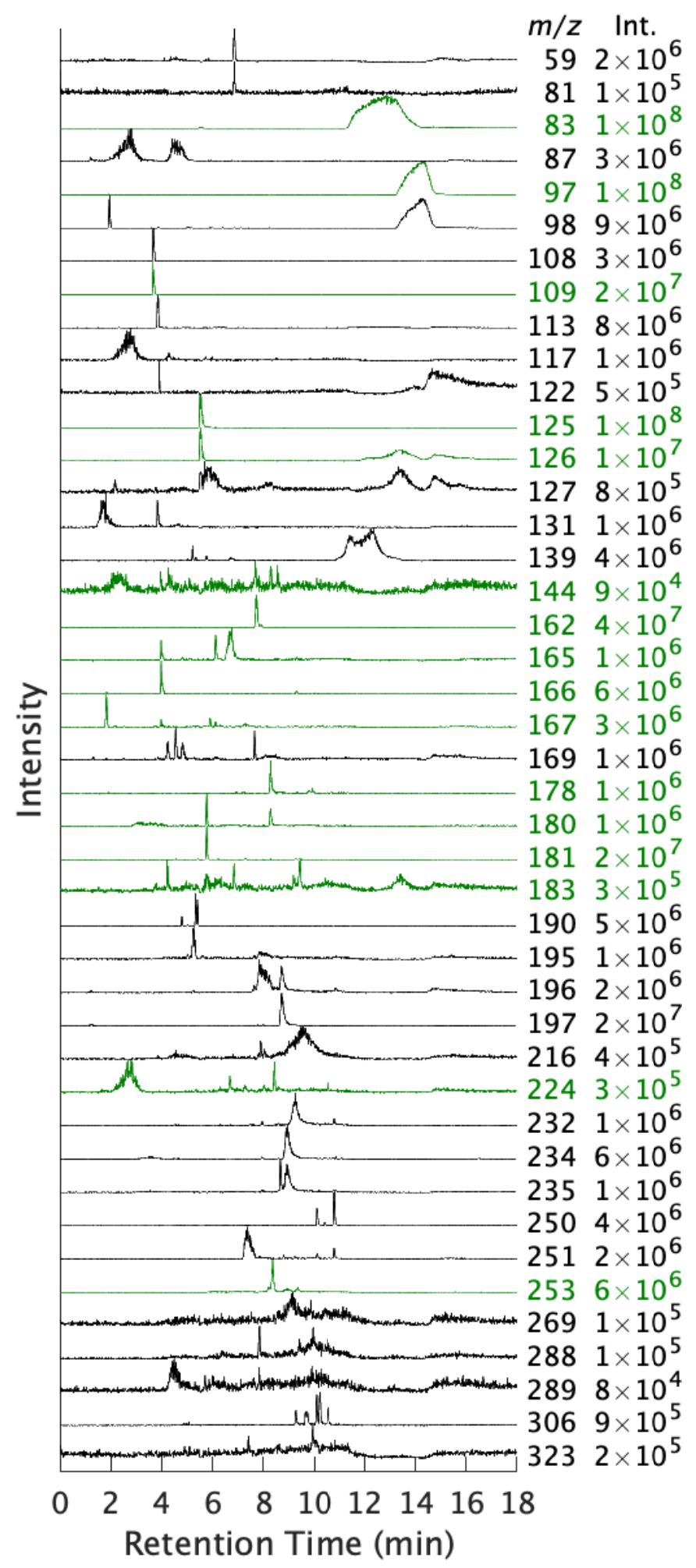

Figure S14: Extracted ion chromatograms of all $\mathrm{m} / \mathrm{z}$ values seen under the conditions described above. All chromatograms have been normalized to their maximum value for ease of viewing due to the very intense signals given by imidazole derivatives. The maximum intensity of the largest peak is given to the right of each trace. The traces shown in green correspond to masses that have been observed in previous work and those shown in black have not yet been published for this system (Lin et al., 2015; Hawkins et al., 2018). 


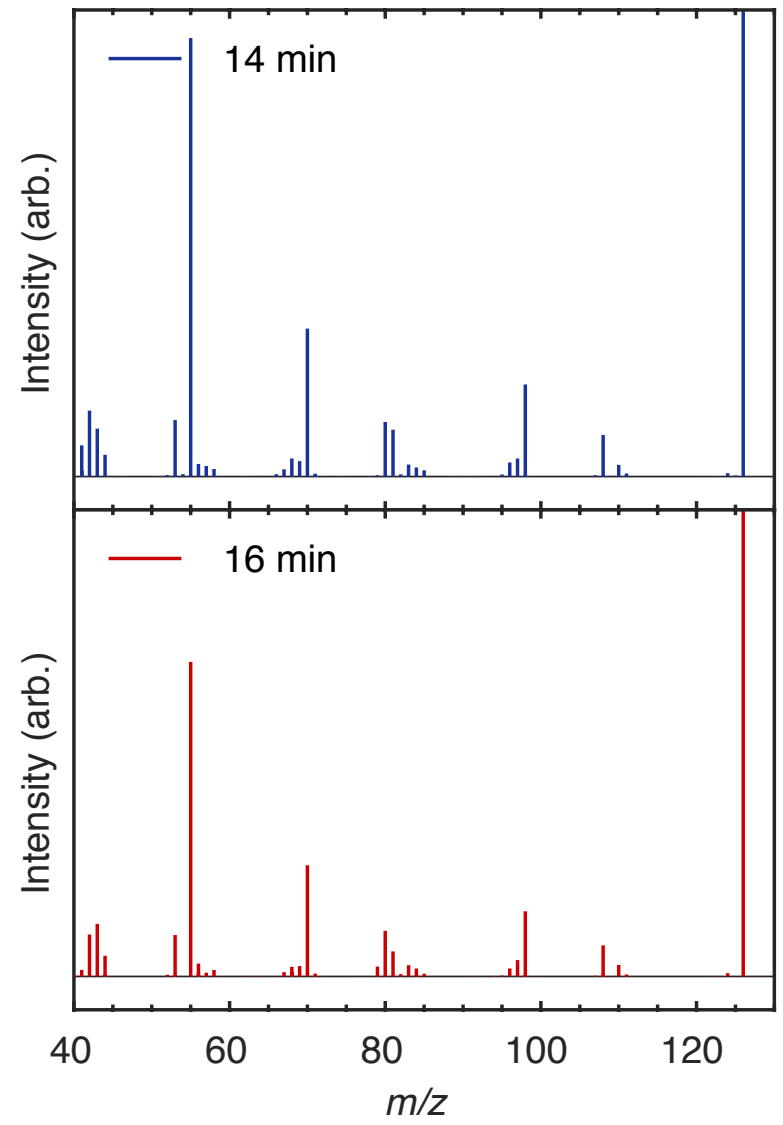

Figure S15: Tandem MS data for $m / z 126$ at the two most intense peaks on the chromatogram. The magnitude of $m / z 126$ is off-scale $(\sim 5 \times$ higher $)$ for ease of viewing the less intense fragment peaks. Note the similarities in fragments for these peaks, indicating that even though they elute at different times, they have very similar structural features and are likely isomers. 


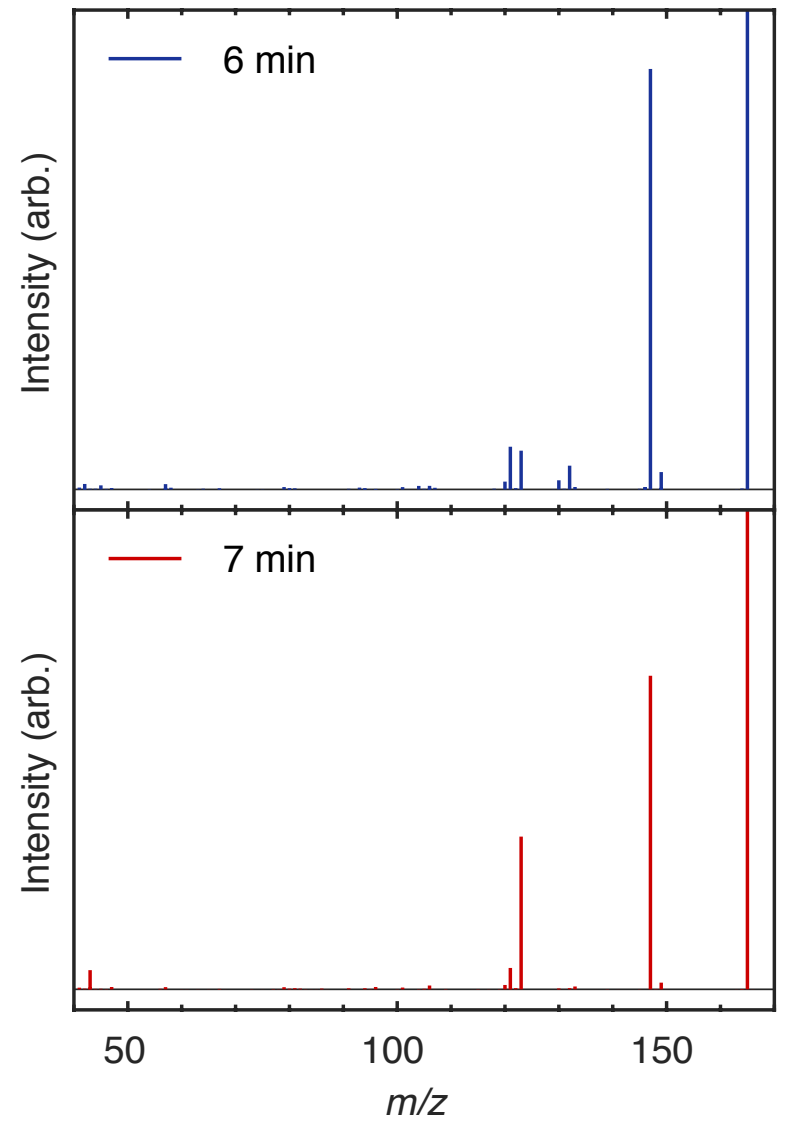

Figure S16: Tandem MS data for $\mathrm{m} / z 165$ at the two most intense peaks on the chromatogram. The magnitude of $m / z 165$ is off-scale $(\sim 2 \times$ higher) for ease of viewing the less intense fragment peaks. Note the similarities in fragments for these peaks, indicating that even though they elute at different times, they have very similar structural features and are likely isomers. 

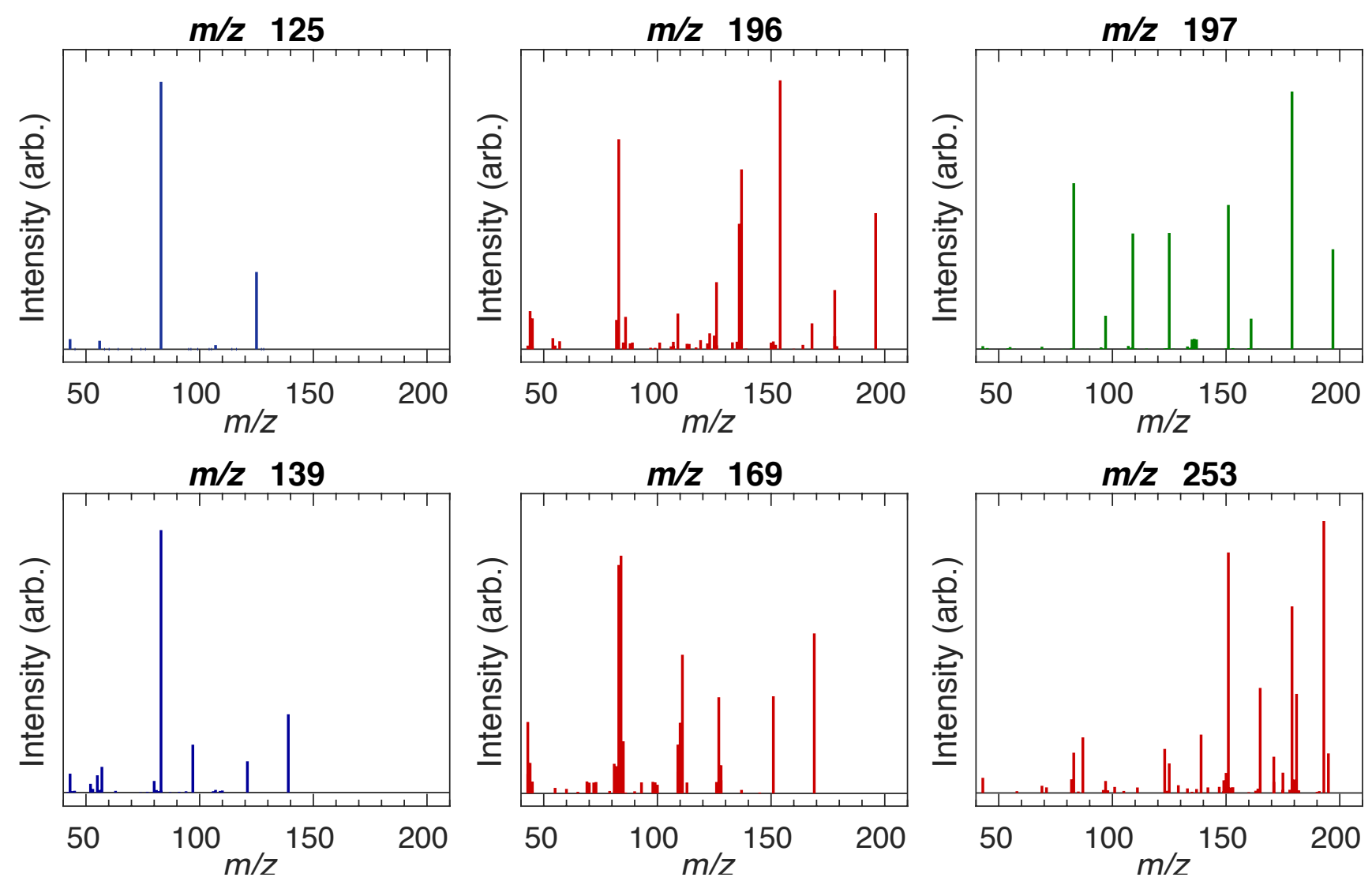

Figure S17: Tandem MS data for several masses with fragments at $m / z 83$, indicating that they contain methylimidazole within their structure. The structures of the masses in the top row have been previously identified as containing methylimidazole, and no structure has been determined for those on the bottom row. 


\section{REFERENCES}

Aiona, P. K., Lee, H. J., Leslie, R., Lin, P., Laskin, A., Laskin, J., and Nizkorodov, S. A.: Photochemistry of Products of the Aqueous Reaction of Methylglyoxal with Ammonium Sulfate, ACS Earth Space Chem., 1, 522-532, 10.1021/acsearthspacechem.7b00075, 2017.

Amarnath, V., Valentine, W. M., Amarnath, K., Eng, M. A., and Graham, D. G.: The mechanism of nucleophilic substitution of alkylpyrroles in the presence of oxygen, Chem. Res. Toxicol., 7, 56-61, 10.1021/tx00037a008, 1994.

Bones, D. L., Henricksen, D. K., Mang, S. A., Gonsior, M., Bateman, A. P., Nguyen, T. B., Cooper, W. J., and Nizkorodov, S. A.: Appearance of strong absorbers and fluorophores in limonene- $\mathrm{O}_{3}$ secondary organic aerosol due to $\mathrm{NH}_{4}{ }^{+}$-mediated chemical aging over long time scales, J. Geophys. Res.: Atmos., 115, D05203, 10.1029/2009JD012864, 2010.

De Haan, D. O., Hawkins, L. N., Kononenko, J. A., Turley, J. J., Corrigan, A. L., Tolbert, M. A., and Jimenez, J. L.: Formation of Nitrogen-Containing Oligomers by Methylglyoxal and Amines in Simulated Evaporating Cloud Droplets, Environ. Sci. Technol., 45, 984-991, 10.1021/es102933x, 2011.

Hawkins, L. N., Welsh, H. G., and Alexander, M. V.: Evidence for pyrazine-based chromophores in cloud water mimics containing methylglyoxal and ammonium sulfate, Atmos. Chem. Phys., 18, 1241312431, 10.5194/acp-18-12413-2018, 2018.

Kampf, C. J., Jakob, R., and Hoffmann, T.: Identification and characterization of aging products in the glyoxal/ammonium sulfate system -- implications for light-absorbing material in atmospheric aerosols, Atmos. Chem. Phys., 12, 6323-6333, 10.5194/acp-12-6323-2012, 2012.

Kampf, C. J., Filippi, A., Zuth, C., Hoffmann, T., and Opatz, T.: Secondary brown carbon formation via the dicarbonyl imine pathway: nitrogen heterocycle formation and synergistic effects, Phys. Chem. Chem. Phys., 18, 18353-18364, 10.1039/C6CP03029G, 2016.

Lin, P., Laskin, J., Nizkorodov, S. A., and Laskin, A.: Revealing Brown Carbon Chromophores Produced in Reactions of Methylglyoxal with Ammonium Sulfate, Environ. Sci. Technol., 49, 14257-14266, 10.1021/acs.est.5b03608, 2015.

Sareen, N., Schwier, A. N., Shapiro, E. L., Mitroo, D., and McNeill, V. F.: Secondary organic material formed by methylglyoxal in aqueous aerosol mimics, Atmos. Chem. Phys., 10, 997-1016, 10.5194/acp-10-997-2010, 2010. 